\title{
Rumen Manipulation: One of the Promising Strategies to Improve Livestock Productivity-Review
}

\author{
Ulfina Galmessa ${ }^{1}$, Lemma Fita ${ }^{1}$, Tekalign Tadesse ${ }^{2}$ and Amanuel Bekuma ${ }^{2 *}$ \\ ${ }^{1}$ Ethiopian Institute of Agricultural Research, Holeta, Ethiopia \\ ${ }^{2}$ Department of Animal Science, Mettu University, Ethiopia
}

Submission: December 07, 2018; Published: January 22, 2019

*Corresponding author: Amanuel Bekuma, Mettu University, Department of Animal Science, Bedele, Ethiopia

\begin{abstract}
Anaerobic rumen microorganisms mainly bacteria, protozoa and fungi degrade ligno-cellulosic feeds consumed by the ruminants. The ruminants in developing countries are chiefly maintained on low grade roughage and grazing on degraded range land resulting in their poor nutrient utilization and productivity. Hence, manipulation of rumen fermentation is crucial to optimize ruminal fermentation for improving nutrient utilization and productivity of the animals. Chemical additives those selectively affect rumen microbes, introduction of naturally occurring or genetically modified foreign microbes into the rumen and genetically manipulation of existing microbes in the rumen ecosystem are the available rumen manipulation strategies. Accordingly, rumen protozoa are getting rid of by defaunation for plummeting ruminal methane production and increasing protein outflow in the intestine, resulting in get better growth and feed conversion efficiency of the animals. Additionally, probiotics of bacterial and yeast origin are also used in animal feeding to stabilize rumen fermentation, reduced incidence of diarrhea and thus improving growth and feed conversion efficiency of young stalk. In view of feed resource availability more emphasis must be given for manipulating rumen fermentation to increase cellulolytic activity for efficient utilization of low-grade roughage thereby improves livestock production and productivity.
\end{abstract}

Keywords: Defaunation; Feed Conversion Efficiency; Probiotics; Rumen Manipulation

\section{Introduction}

Continuing increase in the human population consume an ever-greater fraction of earth's food, among which proteins are extremely important. Some proteins formed in plants especially as reserve food in the seeds and meat, milk, wool/fur and hide of grazing mammals have long been important source of food protein and protective clothing for human. Among these grazing animals, the ruminants are predominant animal species for human consumption [1]. The rumen, which is located at the beginning of the tract of ruminants (cattle, buffalo, sheep and goats), contain different types of microbes mainly, bacteria, protozoa and fungi, and plays a great role in the digestion of ligno-cellulosic food which are inedible for human consumption. Structural carbohydrate and high-quality microbial protein are synthesized by ruminal microbial activity. Anaerobic fermentation of feed in the rumen is the result of physical and microbiological activities which convert components of the diet to products which are useful (VFA and microbial protein) and useless (methane and carbon dioxide) to the host animals [2].

Currently, many researches and reviews have been done on rumen studies, rumen ecology and manipulation and there are increasing interests to continue further studies [3]. In tropics, low-quality roughages, crop-residues and industrial by-products which contain high level of ligno-celluloses, poor in fermentable carbohydrate and good quality protein are given for ruminants. In tropical country, most of ruminants have been fed on low-quality roughages, agricultural crop-residues, and industrial by-products which basically contained high levels of lingo-celluloses materials, low level of fermentable carbohydrate as well as low level of good quality protein. Besides this, prolong dry season and prevailing harsh environment condition (high temperature, poor fertile soil and scarcity feeds in quantity and quality throughout the year would influence rumen fermentation of quantity and quality [4].

To evade this problem, strategies aiming to optimize rumen manipulation is key to improve feedstuffs utilization and then to optimize ruminant production. The main challenges nowadays in ruminant production are to reduce feeding costs, improve products quality and diminish the impact of production on environment. The use of unconventional feedstuffs may contribute to decrease feeding cost and environmental impact through reduced methane emissions. In addition, improving products quality (i.e. fatty acid profile in milk) has been also shown potentially achievable by using such ingredients in the diet [5]. Therefore, there is the need to look at the recent advances and manipulation of rumen in the 
improvement of animal nutrition to boost livestock productivity. The objective of this review work is, therefore, to review the research work done so far regarding manipulation of rumen to enhance livestock productivity.

\section{Rumen Fermentation}

The rumen is fermentation vat that can prepare end-products like volatile fatty acids and microbial proteins as major energy source and protein for the ruminant host. Microorganisms in the rumen degrade nutrients to produce volatile fatty acids (short chain fatty acids) and synthesize microbial protein as an energy and protein supply for the ruminant animal, respectively. The more efficient the rumen is, the better the fermentation end-products being synthesized [6]. In ruminants, the main fermentation processes of nutrients in the consumed feed ration occur first in the fore-stomach i.e., the rumen. These processes to a great extent are possible because of the microorganisms colonizing it. The microbial population in the rumen consists of bacteria at $10^{10}$ cells $/ \mathrm{ml}$, protozoa at $10^{6}$ cells $/ \mathrm{ml}$, fungi at $10^{3}-10^{7}$ cells $/$ $\mathrm{ml}$ and methanogens at $10^{9}$ cells per $\mathrm{ml}$ [7]. Rumen manipulation has, therefore, been proved to be effective to increase the efficient use of local feed resources and enhance productivity in ruminants [8]. However, microbial rumen fermentation process has energy losses as methane, and protein losses as ammonia $\mathrm{N}$, inefficiencies that limit the production performance of the host animal and contribute to the release of greenhouse gas pollutants to the environment. Any sustainable solution to inhibit loss of energy, as methane and protein, as ammonia $\mathrm{N}$, should be practical, cost effective and have no substantial adverse effect on the profitability of ruminant livestock production.

Rumen fermentation of carbohydrates and proteins in ruminants is accompanied by loss of energy and amino $\mathrm{N}$, respectively. In fact, enteric methane emission in ruminants, which is produced via fermentation of feeds in the rumen and lower digestive tract by methanogenic archaea represents a loss of $2 \%$ to $12 \%$ of gross energy of feeds and contributes to global greenhouse effects [9]; 8 to $12 \%$ of the digestible energy ingested by ruminants is lost in the rumen as methane; and 75 to $85 \%$ of the Nitrogen consumed by dairy cows is excreted in the faeces and urine [9]. Methane up to 15 - 18\% of the digestible energy may be produced where cattle are fed on poor quality forage. This condition results because several essential microbial nutrients may be deficient and microbial growth efficiency in the rumen may be low due to asynchrony of nutrient availability during fermentation. However, the correction of these deficiencies may reduce this to as low as $7 \%$ [10]. According to Donald and Ward [11], about 95\% of the global animal enteric methane is from ruminants a consequence of their large population, body size and intake. Since consumption is largely known and must be predicted, accuracy is limited often by the distribution of animals by class, weight and productivity. The fraction of the diet lost as enteric methane mostly falls into the range of $5.5-6.5 \%$ of gross energy intake for the world's ruminants [11].

\section{Rumen Manipulation}

Manipulating ruminal fermentation involves maximizing the efficiency of feed utilization and increasing ruminant productivity (milk, meat, and wool production). Manipulating ruminal fermentation is intended to enhance beneficial processes, and delete, minimize, alter, processes that are harmful to the host [12].

\section{Why We Need Rumen Manipulation?}

Developing countries are poorest on the world in terms of economic growth and development but are richest in natural resources such as vegetation and large quantity of plan protein that meet out the demand of growing animal and human population; ruminants are important sources of animal protein. In this region, ruminants are fed on poor quality roughage or lignocellulosic agro-industrial by products with or without concentrate supplementation resulting in poor productivity of the animals. Additionally, tropical forages have some important limitation for animals feeding like:

a. Tropical forges have low energy value due to their cell walls contain higher amount of lignin, silica and cutting resulting in lower fermentation of structural carbohydrate [13] and produces less amount of VFA and microbial biomass (microbial protein) after ruminal fermentation in comparison to temperate;

b. Intake of tropical forages by the animals is low due to their poor ruminal digestion and prolonged retention time [13].

c. They are deficient of essential nutrients: contain lower amount of energy, protein [14] and minerals [13].

d. Feeding of tropical forages to the animal's results in imbalance in digestive end products (high acetate and low propionate) which causes inefficient utilization of metabolizable energy [15].

e. Legumes and tree leaves contain anti nutritional compound [16]. Therefore, manipulation of ruminal fermentation to improve the utilization of forages particularly in tropical and developing countries to maximize the productivity of animals by using available resources.

\section{Methods of Rumen Manipulation}

\section{Genetic Rumen Manipulation}

Genetically modifying the naturally available microorganism in the rumen enhances their capacity of defined functions or to add new functions [17]; and introduction of diverse genes into gut microorganisms have been explored [18]. The genetically modified microorganisms are either able to digest fibrous components and lignins of forage, or degrade toxins, synthesize essential amino acids, reduce ruminal methane production and tolerate acids [19]. Introducing new species or strains of microorganisms into the gut [20], like the former approach has a great potential to increase digestibility of feedstuffs and to improve animal production. 


\section{Non-Genetic Rumen Manipulation}

Probiotics: The digestion process in ruminant occurs by chemical reaction and fermentation provided by the rumen microbial flora. During the last decade, the rumen and intestinal microbial flora, which are essential to the animal's health, has been recognized as the main factors to manipulate for bets growth performance of the animals. However, their equilibrium is constantly threatened by proliferation of undesirable microbes, detrimental to the health and performance of the animals. Therefore, use of live microbial cultures (probiotics) (fungi/yeast and bacteria) are being tried now days as natural feed additives for enhancing rumen metabolic activity and thereby overall animal production [21]. The administration of probiotics had an impact on growth performance, disease resistance, improving animal production and providing a cost-effective dietary supplement; microbial feed additives also benefit ruminant nutrition in terms of live weight gain and milk production of the animals in the tune of $7-8 \%$ [22].

\section{Factors Influencing Effect of Probiotics Feeding on Ani- mal Performances}

Effects of probiotics supplementation on dry matter intake by the animals are incompatible. Supplementation of yeast in the animal's feed improved it palatability and increase in feed intake as glutamic acid produced by yeast is responsible for improvement in the taste of feed stuffs [23]. Even though feeding probiotics to the animals improves digestibility of dry matter, organic matter, crude protein and fiber in yeast fed animals and moreover, higher retention of nitrogen and energy, the effects have been variable, and the response influenced by the type of diet, physiological state of the animals and microbial strain employed [24]. Positive response on milk production has been reported in yeast fed animals [25]; and the response was greater with diets containing the higher proportion of concentrate [8] Incidence of diarrhea reduced due to feeding of probiotics to the young calves [26]. There was considerable reduction in the number of total coliform bacteria in the rumen liquor as well as faces of calves fed probiotics in their diet, irrespective of the chemical composition of the ration offered to the animals [27].

\section{Defaunation}

Defaunation is the process of making the rumen of animals free of rumen protozoa and the animal is called defaunated animal. According to [2] even though protozoa may be non-essential for ruminant, still they have significant role to play in the rumen metabolism specially to stabilize the rumen. Rumen protozoa contribute $40-50 \%$ of the total microbial biomass and enzyme activities in the rumen [28].

\section{Methods of Defaunation}

Separation of newborn animals from their dams after birth and preventing them from any contact with the adult ruminant animal is one of the methods of producing defaunated animals. The newborn animals should be separated 2 to 3 days after birth; and during this time the newborn animals gets contaminated with the native bacterial population but do not get rumen ciliate protozoa [29]. Using of chemicals (copper sulphate, manoxol and sodium lauryl sulphate) are another method of defaunation used for obtaining animals free from rumen ciliate protozoa [2]. The ciliate protozoa are very much sensitive to change in rumen $\mathrm{P}^{\mathrm{H}}$ and adversely affected when the $\mathrm{p}^{\mathrm{H}}$ of the rumen falls below 5.8 and if the rumen $\mathrm{p}^{\mathrm{H}}$ falls below 5.0, the ciliate protozoa are being eliminated. Therefore, offering high energy feed (especially cereal grains like barley, maize etc.) to the starved (for 24 hours) animals creates acidic condition in the rumen and rumen $\mathrm{P}^{\mathrm{H}}$ fall below 5.0. This fall in rumen $\mathrm{P}^{\mathrm{H}}$ eliminates the ciliate protozoa completely and the animal becomes defaunated [30].

\section{Effect of Defaunation on the Rumen Ecosystem Ru- men Microbes}

Defaunation increase the number of amylolytic bacteria due to elimination of nutritional competition between bacteria and protozoa for using starch, whereas the cellulolytic bacterial population becomes decreased; fungal populations in the rumen also increase [31]. According to the report of [2] defaunation is also significantly decrease the methane production compared with the normal faunated animals. Rumen protozoa contribute hydrogen moiety to produce methane by the methanogenic bacteria [32].

\section{Conclusion and Area of Future Research}

Rumen is a natural fermentative anaerobic system which should be manipulated essentially by altering the composition of rumen microflora. There is ample scope to manipulate the rumen by feeding local plants or tree leaves or agro industrial by products to defaunate the animals for improving its productivity. Introduction of naturally occurring microorganism from digestive system of one species to another species for efficient degradation of plant toxins as well as for efficient utilization of nutrients will be one of the major thrust area in near future for rumen manipulation. Even though genetically manipulation of rumen microorganism for efficient ruminal fermentative digestion has an enormous biotechnological potential; however, in developing countries, more prominence should be given for manipulating the rumen to increase cellulolytic activity for efficient utilization of low-grade roughage. Based on the above conclusion the following areas need future research endeavors:

a. Screening of non-conventional animal feeds specially tree leaves for anti-protozoal activity;

b. Standardization of defaunation method for its implication at farmer level;

c. New species/ strains of microorganism should be screened to use as probiotics; and mechanism of action of probiotic should be studied thoroughly.

\section{Acknowledgement}

The authors would like to thank those researchers conducting their research on rumen manipulation and related topics; because their findings are pillar for this review. 


\section{References}

1. Bradford GE (1999) Contribution of animal agriculture to meeting global human food demand. Livest Prod Sci 59: 95-112.

2. Santra A, Karim SA (2002) Influence of ciliate protozoa on biochemical changes and hydrolytic enzyme profile in the rumen ecosystem. J Appl Microbiol 92: 801-811.

3. Khampa S, Chaowarat P, Chumpawadee S, Singhhalert R, Wanapat M (2009) Effect of malate and cassava hay in high-quality feed block on ruminal fermentation efficiency and digestibility of nutrients in dairy steers. Asian Journal of Animal Science, 3: 33-38.

4. Wanapat M (2005) Enhancing ruminant productivity in the tropics by rumen manipulating with local feed resources. In: Proceedings of the International Conference Integrating Livestock-Crop Systems to Meet the Challenges of Globalization. November 14-18, 2005. Held at Sofitel Raja Orchid, Khon Kaen University, Thailand, 1: 285-296.

5. Lee SS, Ha JK, Cheng KJ (2000) Influence of an anaerobic fungal culture administration on in ruminal fermentation and nutrient digestion. Anim Feed Sci Technol 88: 201-217.

6. Kamra DN (2005) Rumen microbial ecosystem. Current Science, 89: 134-135.

7. Gebrehiwot Tadesse (2014) Rumen Manipulation for Enhanced Feed Utilization and Improved Productivity Performance of Ruminants: A review. Momona Ethiopian Journal of Science (MEJS) 6(2): 3-17.

8. Hess HD, Beuret RA, Lötscher M, Hindrichsen IK, Machmüller A, et al. (2004) Ruminal fermentation, methanogenesis and nitrogen utilization of sheep receiving tropical grass hay-concentrate diets offered with Sapindus saponaria fruits and Cratylia argentea foliage. Animal Science 79: 177-189.

9. Patra AK (2012) Enteric methane mitigation technologies for ruminant livestock: a synthesis of current research and future directions. Environ Monit Assess, 184(4): 1929-1952.

10. Gworgwor ZA, Mbahi TF, Yakubu B (2006) Environmental Implications of Methane Production by Ruminants: A Review. Journal of Sustainable Development in Agriculture and Environment 2(1): 794-867.

11. Donald EJ, Ward GM (1996) Estimates of animal methane emissions Environmental monitoring and assessment, 42(1-2): 133-141.

12. Nagaraja TG, Newbold CJ, Van Nevel CJ, Demeyer DI (1997) Manipulation of ruminal fermentation. In The Rumen Microbial Ecosystem. Hobson PN, Stewart CS (Eds.), ( $\left.2^{\text {nd }} e d n\right)$, Blackie Academic \& Professional, New York, USA, pp. 523-632.

13. Dominguez Bello MG, Escobar A (1997) Rumen manipulation for the improved utilization of tropical forages. Anim Feed Sci Technol 69: 91 102.

14. Minson DJ (1980) Nutritional differences between tropical and temperate pasture. In: Grazing Animals Marely FHW (Eds.), Elsevier, Amesterdam, pp. 143-157.

15. Egan AR, Frederick F, Dixon RM (1986) Improving efficiency of use supplements by manipulation of management procedures. In: Ruminal Feeding System Utilizing Fibrous Agricultural Residues. Dixon RM (Eds.), International Development Program of Australian Universities and Colleges (IDP), Canberra, Australia, pp. 69-81.

16. MacRae JC, Lobley GE (1982) Some factors which influence thermal energy loss during the metabolism of ruminants. Livest Prod Sci 9: 477-479.
17. Jansen DH (1975) Ecology of plants in the tropics. In: Studies in Biology. Arnold E (Eds.), UK, 58: 66.

18. Chang H (1996) Genetic engineering to enhance microbial interference and related therapeutic applications. Nature Biotecnol 14: 423-431.

19. McSweeney CS, Dalrymple BP, Gobius KS, Kennedy PM, Krause DO, et al. (1999) The application of rumen biotechnology to improve the nutritive value of fibrous feed stuffs: pre and post ingestion. Livest Prod Sci 59: 265-283.

20. Forsberg CW, Cheng KJ, Krell PJ, Phillips JP (1993) Establishment of rumen microbial gene pools and their manipulation to benefit digestion by domestic animals. In: Proceeding of the Seventh World Conference on Animal Production, Edmonton, Alberta, 1: 281-316.

21. Stewart CS, Fonty G, Gouet PH (1988) The establishment of rumen microbial communities. Anim Feed Sci Technol 21: 69-97.

22. Fuller R (1989) A Review: Probiotics in man and animals. J Appl Bacteriol 66: 365-378.

23. Wallace RJ, Newbold CJ (1993) Rumen fermentation and its manipulation: The development of yeast culture as feed additives. In: Biotechnology in the Feed industry. Fuller R (Eds.), Chapman and Hall, London, UK, pp. 173-192.

24. Agarwal Neeta (2002) Microbial feed additives for ruminants. In: Recent Advances in Rumen Microbiology Kamra DN, Neeta Agarwal LC, Chaudhary, Agrawal DK (Eds.), IVRI Publication, Izatnagar, India, p. 47-56.

25. Moloney AP, Drennan MJ (1994) The influence of the basal diet on the effects of yeast culture on ruminal fermentation and digestibility in steers. Anim Feed Sci Technol 50: 55-73.

26. Huber JT, Sullivan J, Taylor B, Burgos A, Gramer S (1990) In: Biotechnology in the Feed Industry Lyons TP (Eds.), Alltech Technical Publications, Nicholasville, USA, p. 35-38.

27. Saha SK, Senani S, Padhi MK, Shome BR, Rajeswari Shome et al. (1999) Microbial manipulation of rumen fermentation using Saccharomyces cervisiae as probiotics. Current Sciences 77: 696-697.

28. Kamra DN, Agarwal N, Chaudhary LC, Sahoo A, Pathak NN (1997) Effect of feeding probiotic (Lactic acid producing bacteria) on the growth of coliform bacteria in the gastrointestinal tract of crossbred calves. In: Proceeding of VIII Animal Nutrition Research Worker's Conference, Chennai, India, pp. 130-131.

29. Agarwal Neeta, Kewalramani N, Kamra DN, Agrawal DK, Nath K (1991) Hydrolytic enzymes of buffalo rumen: Comparison of cell free rumen fluid, bacterial and protozoal fractions. Buff J 2: 203-207.

30. Fonty G, Jouany JP, Senaud J, Gouet PH, Grain J (1984) The evolution of microflora, macrofauna and digestion in the rumen of lambs from birth to four months. Can J Anim Sci pp. 165-169.

31. Nhan NTH, Hon NV, Ngu MT, Von NT, Preston TR, et al. (2001) Practical application of defaunation of cattle on farms in Vietnam: Response of young cattle fed rice straw and grass to a single drench of ground nut oil. Aisan-Aus J Anim Sci 14: 485-490.

32. Smet De S, Demeyer DI, Van Nevel CJ (1992) Effect of defaunation and hay: concentrate ratio on fermentation, fiber digestion and passage in the rumen of sheep. Anim Feed Sci Technol 37: 333-344. 


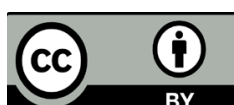

This work is licensed under Creative Commons Attribution 4.0 License

DOI: 10.19080/JDVS.2019.09.555758

\section{Your next submission with Juniper Publishers} will reach you the below assets

- Quality Editorial service

- Swift Peer Review

- Reprints availability

- E-prints Service

- Manuscript Podcast for convenient understanding

- Global attainment for your research

- Manuscript accessibility in different formats

( Pdf, E-pub, Full Text, Audio)

- Unceasing customer service

Track the below URL for one-step submission https://juniperpublishers.com/online-submission.php 